\title{
Vaginal Hemorrhage
}

National Cancer Institute

\section{Source}

National Cancer Institute. Vaginal Hemorrhage. NCI Thesaurus. Code C26945.

Bleeding originating from the vagina. 